\title{
TRANSPLACENTAL HEPATO-CURATIVE POTENTIAL OF GARLIC AGAINST SODIUM ARSENATE INDUCED OXIDATIVE STRESS IN MICE
}

\author{
S. Andleeb ${ }^{1}$, N. Aslam¹, M. Habib ${ }^{2}$, H. Zaman², S. Rehman², M. Imran³ and Z. Abbas²* \\ ${ }^{1}$ Department of Zoology, Division of Science and Technology, University of Education, College Road, Lahore \\ ${ }^{2}$ Department of Microbiology and Molecular Genetics, University of the Punjab, Quaid-e-Azam Campus, Lahore, Pakistan \\ ${ }^{3}$ Institute of Chemistry, University of the Punjab, Quaid-e-Azam Campus, Lahore, Pakistan \\ ${ }^{*}$ Corresponding author's e-mail: zaigham.mmg@gmail.com
}

\begin{abstract}
Inorganic arsenic is a well-known toxicant and carcinogen. Millions of people in world are being affected by arsenic mainly through drinking water. Objectives: To evaluate toxic effects of sodium arsenate $\left(\mathrm{Na}_{3} \mathrm{AsO}_{4}\right)$ and assess protective role of garlic (Allium sativum) in minimizing its toxicological effects. Methodology: In this study, 20 pregnant female mice were divided into 4 groups. Group I (Control) was healthy control and Group II (Dose group) was orally administered with $50 \mathrm{mg} / \mathrm{kg}$ of $\mathrm{Na}_{3} \mathrm{AsO}_{4}$ on the "Gestation day 6" for consecutive 6 days. Group III (Dose+ Antidote group) mice were administered with $50 \mathrm{mg} / \mathrm{kg}$ of $\mathrm{Na}_{3} \mathrm{AsO}_{4}$ and garlic extract $(30 \mathrm{mg} / \mathrm{kg})$ with a gap of one hour. Group IV (Antidote Group) was administered orally with garlic extract $(30 \mathrm{mg} / \mathrm{kg})$. Results: Pregnant female mice were sacrificed at $18^{\text {th }}$ day of gestation, $\mathrm{Na}_{3} \mathrm{AsO}_{4}$ affected weight, limbs, and size of the fetus. It also caused pyknosis, necrosis and increased sinusoidal space, fibrosis in both mother and fetal liver of mice. High mortality rate and pregnancies loss were observed in Group II. On the other hand, garlic showed strong antioxidant activity which neutralized oxidative stress condition in both mother and fetal liver of mice in Group III. Conclusion: Our findings indicated that $\mathrm{Na}_{3} \mathrm{AsO}_{4}$ is a potential toxic metalloid that can cross placenta and garlic is equally effective in ameliorating these toxicities in mice.
\end{abstract}

Keywords: Allium sativa, Nrf2 signaling pathway, mice, Mus musculus.

https://doi.org/10.36899/JAPS.2021.1.0196

Published online August 26, 2020

\section{INTRODUCTION}

Arsenic is a toxic metalloid that exists ubiquitously in the environment mainly in drinking water (Amer et al., 2016). It is also used widely in medicine for the treatment of diabetes, psoriasis, syphilis, skin ulcers, joint diseases, leukemia, and neoplastic diseases (KulikKupka et al., 2016; Riaz et al., 2017). Arsenic has previously been reported as class I carcinogen by The International Agency for Research on Cancer (IARC) as it induces skin, lung, liver and urinary bladder cancer (Saint-Jacques et al., 2014; Bali et al., 2016; Lynch et al., 2017) prostate cancer (Roh et al., 2017). It causes histopathological changes in kidney and liver (Jalaludeen et al., 2016; Li et al., 2018) myocardial infarction (Mandal, 2017), male infertility (Wang et al., 2016) and oxidative stress (Bali et al., 2016; Han et al., 2017). According to the WHO recommendation arsenic dose level in drinking water is $10 \mu \mathrm{g} / \mathrm{L}$ (Rasheed et al., 2017). Usually urine is used as biomarker of arsenic exposure (Wongsasuluk et al., 2018). Oxidative stress induced by arsenic leads to the activation of nuclear factor erythroid 2-related factor 2 (Nrf2) pathway (Han et al., 2017), nuclear factor-kappa B (NF-kappaB), p53, expression of miR-34a and Bax (Choudhury et al., 2016), Nrf2/HO-1 signaling pathway (Li et al., 2017). Biomethylation of inorganic arsenic (iAs) through methyl transferase (AS3MT) into mono and dimethylated forms is declared as a major detoxification pathway. The presence of arsenic in the trivalent oxidation state accusing arsenic as toxin as well as carcinogen while, arsenic trioxide was shown to be protective against acute promyelocytic leukemia (Khairul et al., 2017). Nrf2 is a ubiquitous transcription factor that expressed in the organs, like liver and is involved in detoxification in response to oxidative stress, apoptosis, and abnormal inflammatory as well as immune responses by regulating the genes like NQO-1 (NAD (P) H: Quinone oxidoreductase 1), catalase, SOD, HO1 (heme oxygenase 1), GSH (glutathione) and many other enzymes having antioxidant-response element (ARE) in their promoters (Habib et al., 2020). It is itself regulated by a repressor protein Keap1, which can sense a change in cellular homeostasis (Tang et al., 2014; Zhao et al., 2016). In oxidative anxiety, Nrf2 is not degraded, but rather goes to the core, where it ties to DNA promoter areas and starts interpretation of anti-oxidative qualities. At that point where ubiquitin binds with $\mathrm{Nrf2}$, transported to the proteasome, where it is degraded and its segments are reused. When Nrf2 is not ubiquitinzed, it aggregates in the cytoplasm and translocate into the core (SaintJacques et al., 2014). Meanwhile, conventional use of Garlic was found quite effective against immune and 
cardiovascular diseases, cancer, liver, renal toxicities, hypertension, hypercholesterolemia, diabetes, oxidative stress, and tumors (Dhawan and Jain, 2005; Butt et al., 2009; Majewski, 2014; Amer et al., 2016; Rasheed et al., 2017) and for the improvement of visual memory and attention (Tasnim et al., 2015). Such properties are due to biologically active antioxidant substances like alliinase, allicin, alliin, and S-allylcysteine (Santhosha et al., 2013; Majewski, 2014). Garlic derivatives including Allyl methyl sulphide, diallyl sulphide, and diallyl disulphide and diallyl trisulfide are even more effective antioxidants (Castro et al., 2010; Das and Chaudhuri, 2014; Miltonprabu and Sumedha, 2014). Allicin is produced on crushing of the garlic clove. Disulfide Sallylmercaptoglutathione (GSSA) the product of the reaction between allicin and reduced glutathione (GSH) has high antioxidant properties (Zhang et al., 2016). Diallyl disulfide (DADS) is a stable antioxidant of garlic and can ameliorate the arsenic-induced cytotoxicity, production of reactive oxygen species, lipid peroxidation and DNA damage (Das and Chaudhuri, 2014). The basic purpose of the present study was to investigate the damaging effects of sodium arsenate on liver, developmental abnormalities of sub lethal dose and protective role of garlic in neutralizing the intensities of these toxicities. This objective was achieved by comparative morphological, morphometric, molecular, histological and total estimation of arsenic level both in maternal and fetal liver tissue.

\section{MATERIALS AND METHODS}

Chemical Reagents: Sodium arsenate $\left(\mathrm{Na}_{3} \mathrm{AsO}_{4}\right)$ from (GTI Laboratories Supplies) was used to find out the toxic effect in pregnant mice mother and prenatal mice. 2,2-Diphenyl-1-picrylhydrazyl (DPPH) was used to check the antioxidant response of garlic. Trizol (Thermo Fisher Scientific USA) was used to extract RNA for molecular analysis. Thermo scientific first strand cDNA synthesis kit (USA) was used to prepare cDNA.
Experimental animals: For this study a prior approval was obtained by Institutional Biosafety and Ethical Committee of MMG, University of the Punjab, Lahore. In total $30 \mathrm{Male} \mathrm{BALB} / \mathrm{c}$ mice $(30 \mathrm{~g} \pm 4.3 \mathrm{wt}$ and $8-10$ weeks of age) were kept in laboratory animal house of Department of Microbiology and Molecular Genetics (MMG), University of the Punjab Lahore Pakistan at constant temperature $(24 \pm 2)$ in natural light-dark cycle (12-12 hrs.). All animals were fed with standard diet and water ad libitum. Twenty pregnant female mice were divided into four groups. Each group containing 5 animals $(n=5)$. Two female mice were caged with one male in different polycarbonated cages for breeding purpose. Sperm positive smear on vagina was checked on regular basis in early morning which indicated the first day of pregnancy (Lu et al., 2014). Doses were administered orally with the help of specific plastic syringe. Group I = Control (untreated) given $0.0 \mathrm{mg} / \mathrm{kg}$ BW of Sodium arsenate. Group II $=0.1 \mathrm{ml}$ of $50 \mathrm{mg} / \mathrm{kg}$ BW of sodium arsenate. Group III $=0.1 \mathrm{ml}$ of $50 \mathrm{mg} / \mathrm{kg}$ BW of sodium arsenate and $0.1 \mathrm{ml}$ of garlic juice $(30 \mathrm{mg} / \mathrm{kg} \mathrm{BW})$ with a gap of one hour. Group IV $=0.1$ $\mathrm{ml}$ of garlic extract $30 \mathrm{mg} / \mathrm{kg} \mathrm{BW}$.

Dose preparation protocol: $50 \mathrm{mg} / \mathrm{kg}$ and $30 \mathrm{mg} / \mathrm{kg}$ doses of sodium arsenate and garlic were used respectively according to the (Podder et al., 2014; Tasnim et al., 2015) protocols. The dose was prepared by adding $125 \mathrm{mg}$ sodium arsenate in $10 \mathrm{ml}$ of distilled water for preparation of stock solution. From stock solution $0.1 \mathrm{ml}$ dose was administered to mice. Cloves of garlic (30 g) were crushed by mortar and pestle by adding $60 \mathrm{ml}$ of distilled water. Crushed mixture was retained as it is to stand for 10 minutes for completion of reaction between allin and allinase then mixture was filtered through filter paper. Dose administration was started from $6^{\text {th }}$ day of gestation for 6 days. Maternal weight gain was observed during whole gestation period from day $1^{\text {st }}$ of gestation to $18^{\text {th }}$ day.as shown in table 1

Table 1. Weight of maternal mice at the onset and $18^{\text {th }}$ day of gestation.

\begin{tabular}{lccc}
\hline Groups & $\begin{array}{c}\text { Initial maternal body } \\
\text { weight } \\
(\mathbf{m g} \pm \boldsymbol{S} \boldsymbol{E M})\end{array}$ & $\begin{array}{c}\text { Weight before Dissection } \\
(\mathbf{m g} \pm \boldsymbol{S} \boldsymbol{E M})\end{array}$ & $\begin{array}{c}\text { Weight after Dissection } \\
(\mathbf{m g} \pm \boldsymbol{S E M})\end{array}$ \\
\hline $\begin{array}{l}\text { Control } \\
(0.00 \mathrm{mg} / \mathrm{kg} \mathrm{BW})\end{array}$ & $24.81+0.4388$ & $45.76+0.3184$ & $31.13+0.8558$ \\
$\begin{array}{l}\text { Dose } \\
(50 \mathrm{mg} / \mathrm{kg} \mathrm{BW})\end{array}$ & $25.46+0.8213$ & $38.44+1.086$ & $28.34+0.5756$ \\
$\begin{array}{l}\text { Dose and Antidote }(50 \\
\mathrm{mg} / \mathrm{kg}, 30 \mathrm{mg} / \mathrm{kg} \mathrm{BW}) .\end{array}$ & $23.90+0.5568$ & $38.20+1.310$ & $27.44+2.157$ \\
$\begin{array}{l}\text { Antidote (Garlic Group) } \\
(30 \mathrm{mg} / \mathrm{kg} \mathrm{BW})\end{array}$ & $24.96+1.147$ & $40.92+0.7493$ & $28.71+0.7208$ \\
\hline
\end{tabular}

A. Number of samples $(n)=5$ 
On the $18^{\text {th }}$ day of gestation, animals were anesthetized by chloroform and dissected. After dissection, embryos were recovered and data was collected by counting number of implants, alive, dead and resorptions are shown in table. 2 .

Table.2. Fetal survival on $18^{\text {th }}$ day of gestation.

\begin{tabular}{|c|c|c|c|c|c|c|}
\hline \multicolumn{7}{|c|}{ Fetuses } \\
\hline Groups & Female & $\begin{array}{c}\text { No. of } \\
\text { Fetuses }\end{array}$ & $\begin{array}{c}\text { Alive } \\
\text { Fetuses }\end{array}$ & $\begin{array}{c}\text { Dead } \\
\text { Fetuses }\end{array}$ & $\begin{array}{l}\text { Implanted } \\
\text { Fetuses }\end{array}$ & $\begin{array}{l}\text { Resorbed } \\
\text { Fetuses }\end{array}$ \\
\hline \multicolumn{7}{|l|}{ Control } \\
\hline \multirow[t]{5}{*}{$(0.00 \mathrm{mg} / \mathrm{kg} \mathrm{BW})$} & $\mathrm{C} 1 \mathrm{~F} 1$ & 10 & 9 & - & - & 1 \\
\hline & $\mathrm{C} 1 \mathrm{~F} 2$ & 11 & 11 & - & - & - \\
\hline & $\mathrm{C} 1 \mathrm{~F} 3$ & 8 & 7 & - & - & 1 \\
\hline & $\mathrm{C} 2 \mathrm{~F} 1$ & 7 & 7 & - & - & - \\
\hline & $\mathrm{C} 2 \mathrm{~F} 2$ & 10 & 10 & - & - & - \\
\hline Dose & $\mathrm{C} 3 \mathrm{~F} 1$ & 4 & 4 & - & - & - \\
\hline \multirow{4}{*}{$(50 \mathrm{mg} / \mathrm{kg} \mathrm{BW})$} & $\mathrm{C} 3 \mathrm{~F} 2$ & 9 & 7 & 2 & & - \\
\hline & $\mathrm{C} 3 \mathrm{~F} 3$ & 7 & 5 & 1 & - & 1 \\
\hline & $\mathrm{C} 4 \mathrm{~F} 1$ & 9 & 7 & 1 & - & 1 \\
\hline & $\mathrm{C} 4 \mathrm{~F} 2$ & 11 & 8 & 2 & 1 & - \\
\hline Dose and Antidote & $\mathrm{C} 5 \mathrm{~F} 1$ & 11 & 10 & 1 & - & - \\
\hline \multirow{4}{*}{$(50 \mathrm{mg} / \mathrm{kg} \mathrm{BW}, 30 \mathrm{mg} / \mathrm{kg} \mathrm{BW})$} & $\mathrm{C} 5 \mathrm{~F} 2$ & 11 & 6 & 4 & 1 & - \\
\hline & $\mathrm{C} 5 \mathrm{~F} 3$ & 10 & 8 & - & 2 & - \\
\hline & $\mathrm{C} 6 \mathrm{~F} 1$ & 7 & 7 & - & - & - \\
\hline & $\mathrm{C} 6 \mathrm{~F} 2$ & 8 & 8 & - & - & - \\
\hline Antidote (Garlic group) & C7F1 & 12 & 12 & - & - & - \\
\hline \multirow{4}{*}{$(30 \mathrm{mg} / \mathrm{kg} \mathrm{BW})$} & $\mathrm{C} 7 \mathrm{~F} 2$ & 8 & 8 & - & - & - \\
\hline & $\mathrm{C} 7 \mathrm{~F} 3$ & 9 & 9 & - & - & - \\
\hline & $\mathrm{C} 8 \mathrm{~F} 1$ & 11 & 10 & - & 1 & - \\
\hline & $\mathrm{C} 8 \mathrm{~F} 2$ & 9 & 8 & - & 1 & - \\
\hline
\end{tabular}

$\mathrm{C}=$ Cage, $\mathrm{F}=$ Females

Histological analysis: Sectioning of both of maternal and fetal liver (fixed in Bouin's fluid) was done using paraffin technique following dehydration, clearing, embedding, sectioning (Fischer et al., 2008) .These sections were later on stained with Haematoxylin and Eosin and studied under microscope SWIFT (M4000-D) and photography was done at LABOMED (LX 400) at $10 \mathrm{X}$ and $40 \mathrm{X}$ for further anatomical studies.

DPPH Assay: Antioxidant activity of garlic was checked by DPPH (2, 2-diphenyl-1-picrylhydrazyl radical) test against Ascorbic acid as control by preparing different dilutions at $517 \mathrm{~nm}$. Free radical scavenging activity of garlic and ascorbic acid at different concentrations were measured as shown in table 3 . A solution of DPPH $(1 \mathrm{ml})$ was prepared in methanol with amount of $3 \times 10^{-4} \mathrm{~mol} / \mathrm{L}$. Afterwards, DPPH solution was added into solutions of garlic and ascorbic acid (2, 4, 6, 8 and $10 \mathrm{mg} / \mathrm{ml})$. All samples were incubated for 20 minutes at room temperature in dark and after incubation time absorbance was measured using a spectrophotometer at $517 \mathrm{~nm}$.

Arsenic Level Estimation: Concentration of arsenic in liver was determined by using inductively coupled plasma -mass spectrometer (ICP-MS). Firstly, tissues were washed with normal saline to remove excess blood followed by addition of nitric acid ( $\mathrm{I} \mathrm{mL}$ ). The resulting mixture was boiled till the evaporation of nitric acid. This process was repeated thrice by adding $1 \mathrm{~mL}$ of nitric acid to ensure complete digestion. Then, $5 \mathrm{ml}$ of deionized water was added to the digest/ash and filtered. The resulting filtrates were then subjected to ICP-MS for determination of arsenic level. All derivatives of arsenic MMA, DMA, As ${ }^{\mathrm{III}}$ and $\mathrm{As}^{\mathrm{V}}$ were finally calculated using ICP-MS (Flora et al., 2011).

Total RNA isolation and Real Time PCR analysis: Liver samples of both mother and fetuses were homogenized at room temperature and RNA was extracted using Trizol (Flora et al., 2011). RNA quantification was done using Nano drop instrument. Equal quantity of RNA $(2 \mu \mathrm{g})$ was reverse transcribed into cDNA with the use of Thermo Scientific First strand cDNA synthesis kit \# 1422. PCR reactions were performed by SYBR Premix Ex Taq II kit USA. The primers for Nrf2 were $\beta$-actin: forward (AAGGCCAACCGTGAAAAGAT) and reverse (GTGGTACGACCAGAGGCATAC), NQO1: forward (AGGGTTCGGTATTACGATCC) and reverse 
(AGTACAATCAGGGCTCTTCTCG) and HO-1: forward (CTGCTAGCCTGGTGCAAGA) and reverse (CCAACAGGAAGCTGA-GAGTGA). The essential conditions for qPCR were: 1 cycle of initial denaturation $\left(95^{\circ} \mathrm{C}\right.$ for $\left.10 \mathrm{~min}\right), 40$ cycles of amplification $\left(95^{\circ} \mathrm{C}\right.$ for $10 \mathrm{~s}$ and $60^{\circ} \mathrm{C}$ for $20 \mathrm{~s}$, and a cooling period $\left(50^{\circ} \mathrm{C}\right.$ for 5 s). The data were presented in relative mRNA levels for normalization of $\beta$-actin, and $\mathrm{Nrf} 2$ control group value was set at $1 . \mathrm{Ct}$ values for each reaction were recorded after reaction completion and by applying formula differences in the expression of these genes were observed Jiang et al. (2009).

Statistical Analyses: Statistical analyses was completed using Graph Pad Prism version 5 software. Standard error of the means and arithmetic mean on all observations were calculated. Comparisons of the mean differences among groups were analyzed by applying ANOVA through Graph Pad Prism software at minimum population significance difference $\mathrm{p}<0.05$ level.

\section{RESULTS}

Fetal abberation in mice treated with sodium arsenate: Maternal liver weight after dissection showed a significant variation between the groups. Liver weight of control group was higher than other groups. Five female mice were used for each experimental group. Pregnant female mice were dissected at $18^{\text {th }}$ day of gestation and maternal weight before and after dissection were recorded (Table I). Body weight of fetus was also determined after birth (Fig. 1).

In control group, morphologically all fetuses were similar and no abnormalities were observed (Fig. 2A). Number of deaths and implants were also observed in (Dose + Antidote) group, these deaths may be due to absorption of arsenic at very early stage gestation period (Table II). In dose group, absence of hind limbs, short growth, hard skin, resorptions were observed as compared with control group (Fig. 2B, 2Cand 2D). However, in (Dose + Antidote) and Antidote groups, fetuses were morphologically similar to control group and no abnormality was observed (Fig.2E and 2F).

There was no significant reduction in length of hind limb in any group (Fig. 3A). However, significant reduction in the fore limb length of fetus was recorded in Dose group when compared to control group (Fig.3B). High mortality rate and pregnancies loss were observed in dose group (Fig. 4).

Antioxidant activity of garlic extract: DPPH test was performed to analyze the antioxidant activity of garlic extract as shown in table 3. Garlic showed maximum percentage of inhibition (90.5\%) at a concentration of 10 $\mathrm{mg} / \mathrm{ml}$. On the other hand, Ascorbic acid showed maximum percentage of inhibition (99.5\%) at a concentration of $10 \mathrm{mg} / \mathrm{ml}$.
Table.3 Free radical scavenging activity by DPPH assay.

\begin{tabular}{ccc}
\hline $\begin{array}{c}\text { Serial } \\
\text { Dilutions } \\
\text { (mg/ml) }\end{array}$ & $\begin{array}{c}\text { \% Inhibition by } \\
\text { Ascorbic acid } \\
\text { (Positive Control) }\end{array}$ & $\begin{array}{c}\text { \% Inhibition by } \\
\text { Garlic }\end{array}$ \\
\hline $\mathbf{2}$ & $95.3 \%$ & $66.70 \%$ \\
$\mathbf{4}$ & $95.5 \%$ & $71 \%$ \\
$\mathbf{6}$ & $96.5 \%$ & $83.4 \%$ \\
$\mathbf{8}$ & $98.5 \%$ & $89.3 \%$ \\
$\mathbf{1 0}$ & 99.5 & 90.5 \\
\hline
\end{tabular}

Sodium arsenate and Garlic caused Morphological changes in maternal and fetal's liver: The histological studies of maternal liver of control group $(0.00 \mathrm{mg} / \mathrm{kg}$ BW) showed the normal structure of hepatocytes and sinusoidal spaces (Fig. 5Aand5B). In maternal liver of dose group $(50 \mathrm{mg} / \mathrm{kg} \mathrm{BW}$ of arsenic), fibrosis, necrosis and increased sinosoidal spaces were observed (Fig. 5Eand5F). Histological results of dose and antidote group $(50 \mathrm{mg} / \mathrm{kg} \mathrm{BW}$ of arsenic and $30 \mathrm{mg} / \mathrm{kg} \mathrm{BW}$ of garlic) showed minor defects and microphotography confirmed the reduced effects of sodium arsenate by garlic in mother liver (Fig. 5Iand5J). Maternal liver of antidote group (30 mg/kg BW of garlic) showed normal strucutre of hepatocytes (Fig. $5 \mathrm{M}$ and $5 \mathrm{~N}$ ). The histological studies of fetal liver of control group $(0.00 \mathrm{mg} / \mathrm{kg} \mathrm{BW})$ showed the normal structure of hepatocytes (Fig. 5C and 5D). The histological studies on fetal liver of dose group $(50 \mathrm{mg} / \mathrm{kg})$ showed severe necrosis, anucleated cells and nuclear pyknosis (Fig. 5G and 5H). Histological results of Dose+ Antidote group $(50 \mathrm{mg} / \mathrm{kg}$ of arsenic and 30 $\mathrm{mg} / \mathrm{kg}$ BW of garlic) showed minor defects and microphotography confirmed the reduced effects of sodium arsenate by garlic in fetal liver (Fig. $5 \mathrm{~K}$ and $5 \mathrm{~L}$ ). Fetal liver of antidote group showed normal strucutre of hepatocytes as compred to control group (Fig. $5 \mathrm{O}$ and $5 \mathrm{P})$.

Accumulation of Arsenic in maternal and fetal liver: Hepatic arsenic level of maternal and fetal liver was analyzed by atomic absorption inductively coupled plasma (ICP) mass spectrometer. Arsenic was not detectable in healthy control group. Level of arsenic was highest in maternal and fetal liver in Dose group. In (Dose + Antidote) group, results of metal estimation showed that garlic plays a crucial role in minimizing the accumulation arsenic in mother and fetal's liver. Level of arsenic was not detected in Antidote group (Fig. 6A and $6 \mathrm{~B})$.

Up regulation of $\mathrm{Nrf2}$ genes due to garlic treatment in mice's liver tissues: RT-PCR was performed to check the expression of two Nrf2 target genes i.e NQO-1 and HO-1. Administration of garlic enhance the Nrf2/ARE signaling pathway thereby increase the expression of antioxidant enzymes. Beta actin was used as a 
housekeeping gene. Data shown as ratios of gene expression levels in untreated control samples to that in treated liver samples after normalization based on the expression of the $\beta$-actin housekeeping gene (Fig. 7)

\section{DISCUSSION}

Arsenic acts as a toxicant and exists almost everywhere on earth's outer layer; almost 200 million people in world suffer from arsenic contamination (Naujokas et al., 2013). Arsenic, exists in organic and inorganic forms with varying oxidation states $(-3,0,+3$, +5 ) (Hsu et al., 2017). It occurs in four distinct forms: dimethyl arsenic acid, arsenite $\left(\mathrm{As}^{+3}\right)$ and monomethyl arsenic acid, entirely the pentavalent and trivalent forms exist more frequently in the environment (Arshad et al., 2015) Pentavalent and trivalent forms of arsenic can be readily absorbed through gastrointestinal tract.

In the current study, high amount of arsenic accumulation was detected in dose group $(50 \mathrm{mg} / \mathrm{kg})$ in maternal and fetal liver as compared to control group. A recent study on mice showed similar results after 6 weeks of arsenic treatment in male mice. Hepatic arsenic level was increased up to 15-20 folds in dose group (Podder et al., 2014; Bodaghi-Namileh et al., 2018; Tasnim et al., 2015) showed similar results after administration of arsenic doses of 20, 50 and $100 \mathrm{mg} / \mathrm{kg} \mathrm{BW.} \mathrm{Arsenic}$ produces reactive nitrogen species (RNS) and reactive oxygen species (ROS). ROS contains reactive metabolites and free radical ions which have unpaired electrons of oxygen molecules and are responsible for the severe liver damages and injuries. However, histological studies on maternal liver of dose group showed fibrosis and increased sinusoidal space when compared to control group. These results support the arsenic based mechanism which involved NADPH oxidase 2 stimulation for vascular degeneration in liver tissues. In sinusoidal endothelial cells, dose of arsenic upregulates the NADPH oxidase 2 based oxidases and is responsible for capillarization which may form fibrosis (Flora et al., 2011). (Das and Chaudhuri, 2014) demonstrated that capillarization promotes the development of fibrosis in liver tissue and induce expression of profibrotic in stellate cells.

Meanwhile, maternal body weight was checked before and after dissection. Maternal body weight was reduced due to the dose of arsenic. This is in line with previously published work who described that body weight of rats becomes reduced due to oral arsenic exposure. Liver weight of maternal mice in arsenictreated group was also reduced when compared with control group which indicates hepatotoxicity due to exposure of arsenic. Significant body weight reduction was observed in fetuses of dose group as compared to control group. This result is supported by the results of Steinmaus (2007) who evaluated that exposure of arsenic from drinking water causes decline in birth weight in human beings during pregnancy (Steinmaus et al., 2007).

Wang in 2016 described that defects in limbs were appeared after oral administration of sodium arsenate dose of $45 \mathrm{mg} / \mathrm{kg}$ from day 6-12 during gestational period in mice (Wang et al., 2016). Fetuses of (Dose + Antidote) group and antidote group showed normal growth of limbs when compared to control group. There was no significant reduction in length of hind limb in any group. However, significant reduction in fore limb length of fetus was recorded in dose group when compared to control group. Vibol (2015) administered intraperitoneal $40 \mathrm{mg} / \mathrm{kg}$ arsenic dose caused defects in limbs and skeletal abnormalities (Vibol et al., 2015). Furthermore, High amount of resorptions and mortalities were observed in high arsenic dose group. Mortality rate and pregnancies lost in arsenic dose showed a positive dose response relationship. Hill evaluated those lower birth rates, higher miscarriage rates are related to high dose exposure of arsenic through drinking water in human (Hill et al., 2008).

ROS induced by sodium arsenate are recognized to upregulate the NQO-1 and HO-1 genes. Real Time PCR was carried out to check the activity of NQO-1 and HO-1 genes in maternal and fetal liver. Oxidative stress is produced due to exposure of arsenic which may activate cell death pathway. In oxidative stress condition when ROS generation is very high Nrf2 transcription factor dissociate from the Keap-1 protein and enter into the cell activates the transcription rate of genes which take prominent role in the up regulation of antioxidant enzymes (Hayes and McMahon, 2009). Garlic has activated the Nrf2 signaling pathway. In our results, dose and antidote group showed low level of transcription of NQO-1 and HO-1 genes as compared to the dose group. Nrf2/HO-1 expression has also been obtained in case of $\mathrm{As}_{2} \mathrm{O}_{3}$ induced hepatic damage (Zhang et al., 2016).

In the present study, it was investigated that arsenic exposure has lethal effects and these could be minimized by garlic extract. Garlic also acts as antimicrobial, hepatoprotective, antitumor, antioxidant and show ameliorative effect against toxicities produced by heavy metals (Agarwal et al., 2013). Coadministration of garlic with arsenic successfully reduced the hepatic arsenic level in (Dose and antidote) group and also secretes arsenic through urination. It was observed that hepatic arsenic level decreases due to regular use of garlic. Amount of arsenic was not transferred into fetal liver due to antioxidant activity of garlic in (Dose and antidote) group. Garlic (Allium Sativum) consists of many organic sulfur compounds which act as active agents (Agarwal et al., 2013). Clastogenic effects of sodium arsenite can be reduced by co administration of garlic (Dose and Antidote Group). Garlic extract increases the release of arsenic from body through urination and reduced the accumulation of arsenic from tissues. This 
protection against arsenic is carried out by thiosulfur compounds existed in garlic extract. Thiosulfur compounds acts as lewis acid and attached to lewis base (Arsenic) to make firm compound to release through urine (Flora et al., 2011). Choudhury described that allicin produced by garlic extract takes part in chelation of arsenic (Choudhury et al., 2016) Sulfur containing compounds of garlic are lipophilic and can easily cross into phospholipid bilayer membranes (Minelli et al., 2012).

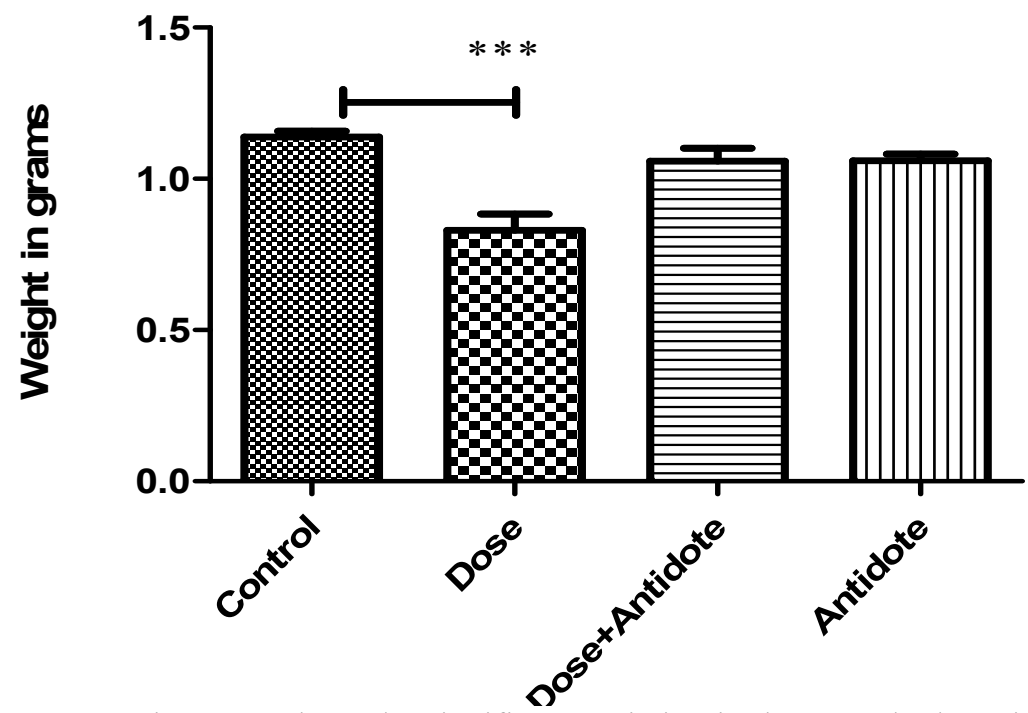

Fig. 1. Body weight of fetuses. Histogram showed a significant variation in the mean body weight of fetuses in control group $(0.00 \mathrm{mg} / \mathrm{kg} \mathrm{BW})$, Dose group (50 mg/kg BW), Dose + Antidote group ( $50 \mathrm{mg} / \mathrm{kg} \mathrm{BW}$ of sodium arsenate and $30 \mathrm{mg} / \mathrm{kg} \mathrm{BW}$ of garlic juice) and Antidote group $\left(30 \mathrm{mg} / \mathrm{kg} \mathrm{BW}\right.$ of garlic) at the time of dissection on $18^{\text {th }}$ day of gestation. Asterisks indicate a significant difference between dose and control group $\left({ }^{* * *}=\mathrm{p}<0.05\right)$.
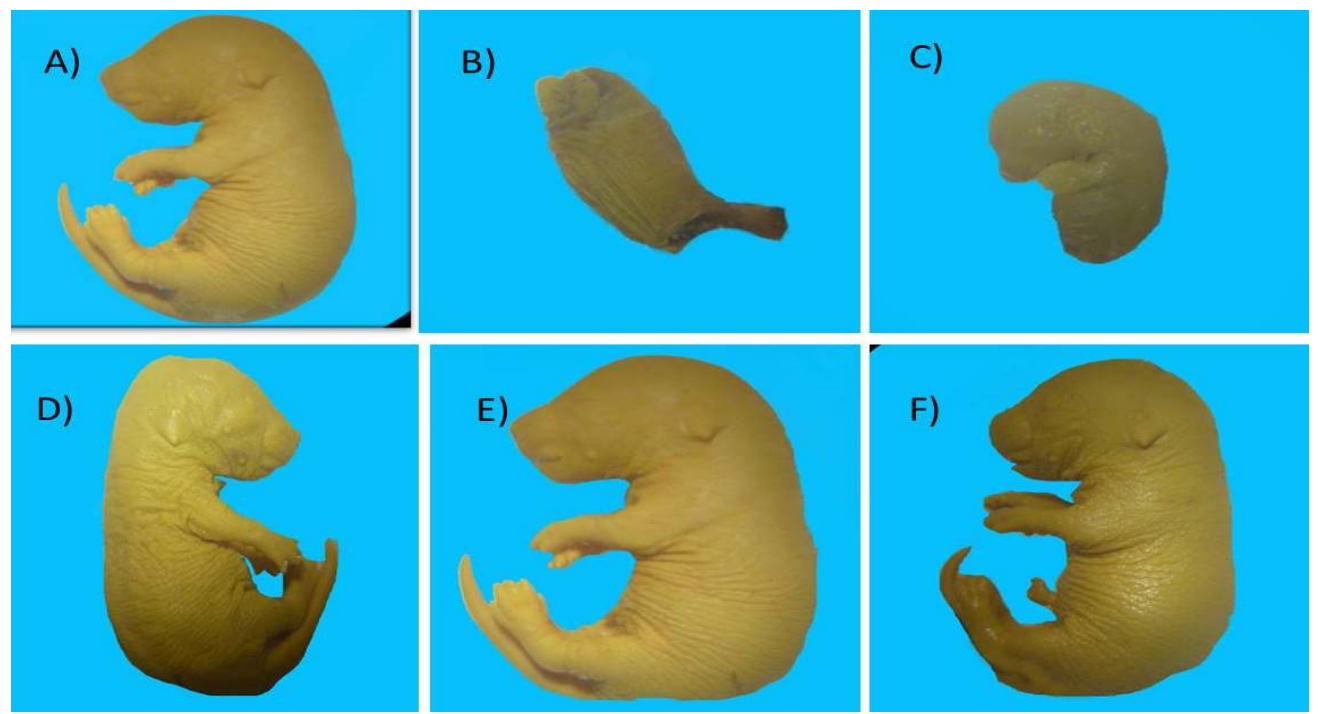

Fig. 2 Fetal aberration in mice treated with sodium arsenate (A): Fetus recovered on $18^{\text {th }}$ day of gestation from female mice of control group $(0.00 \mathrm{mg} / \mathrm{kg} \mathrm{BW})$ showed normal growth. (B): A resorbed fetus recovered from pregnant mice treated orally with sodium arsenate $(50 \mathrm{mg} / \mathrm{kg} \mathrm{B.W})$. (C): Fetus recovered from female mice on $18^{\text {th }}$ day of gestational period after the administration of sodium Arsenate (50mg/kg B.W.) showed extraordinary small size and absence of hind limbs. Note: ah: absence of hind limbs. (D): Fetus recovered from female mice on $18^{\text {th }}$ day of gestation treated orally sodium arsenate showed slight bending of spine (kyphosis) and hard skin. Note: K: kyphosis. (E): Fetus recovered from female mice on $18^{\text {th }}$ day of gestation Dose+ Antidote group showed normal growth and fetus is same as control. (F): Fetus recovered from female mice on $18^{\text {th }}$ day of gestation Antidote group $30 \mathrm{mg} / \mathrm{kg}$ showing showed normal growth. 


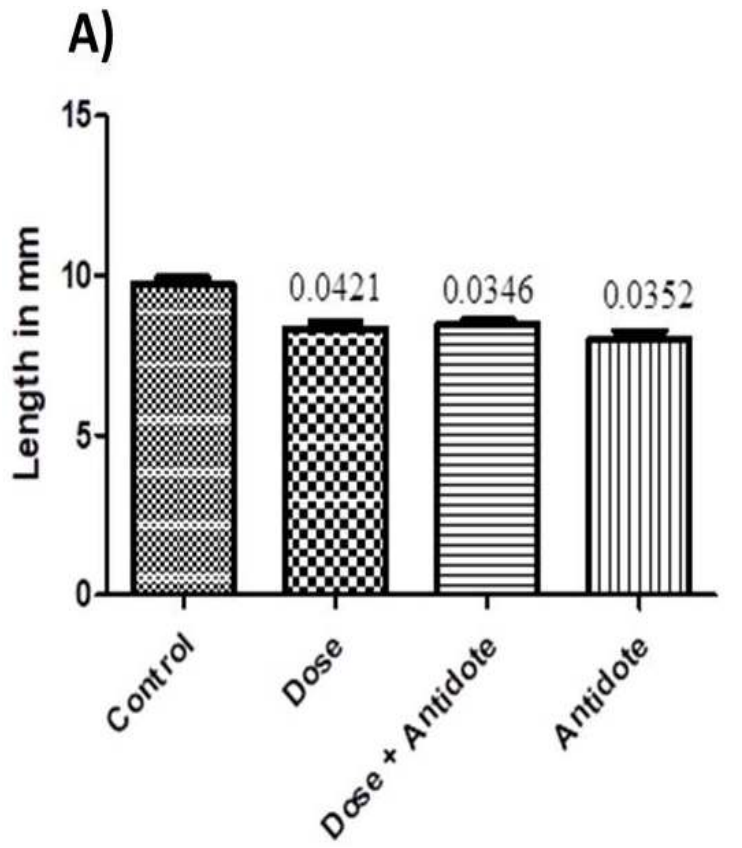

\section{B)}

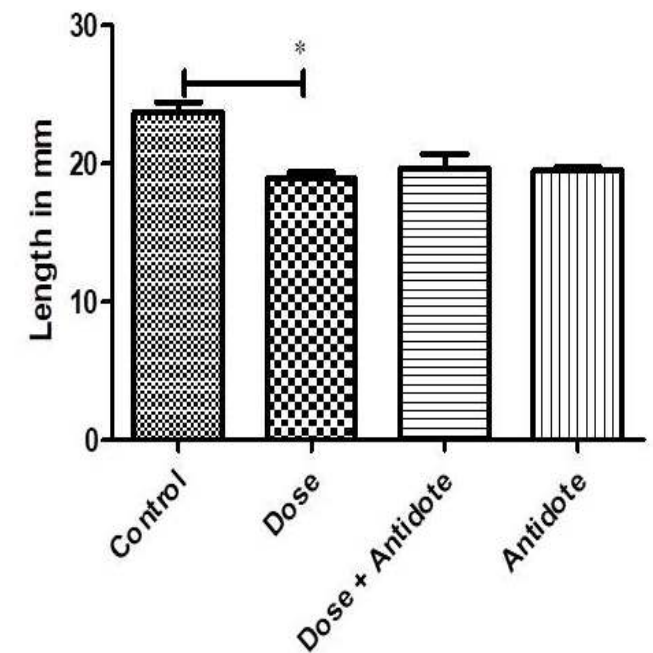

Fig. 3 Length of fore limbs and hind limb (A). Histogram showed a significant variation in the mean fore limbs of fetuses in control group (0.00 mg/kg BW), dose group (50 mg/kg BW), Dose+ Antidote group (50 mg $/ \mathrm{kg} \mathrm{BW}$ of sodium arsenate and $30 \mathrm{mg} / \mathrm{kg} \mathrm{BW}$ of garlic juice) and Antidote group (30 mg/kg BW of garlic) at the time of dissection on $18^{\text {th }}$ day of gestation. Data was represented in Mean + SEM where ( $\mathrm{n}=4$ per group). Asterisks show significant difference against control as $\left({ }^{*}=p<0.05\right)$. (B) Histogram showed no significant variation in the mean hind limb length of fetuses in control group $(0.00 \mathrm{mg} / \mathrm{kg} \mathrm{BW})$, Dose group $(50 \mathrm{mg} / \mathrm{kg} \mathrm{BW})$, Dose + Antidote group $(50 \mathrm{mg} / \mathrm{kg} \mathrm{BW}$ of sodium arsenate and $30 \mathrm{mg} / \mathrm{kg} \mathrm{BW}$ of garlic juice) and Antidote group (30 $\mathrm{mg} / \mathrm{kg} \mathrm{BW}$ of garlic) at the time of dissection.

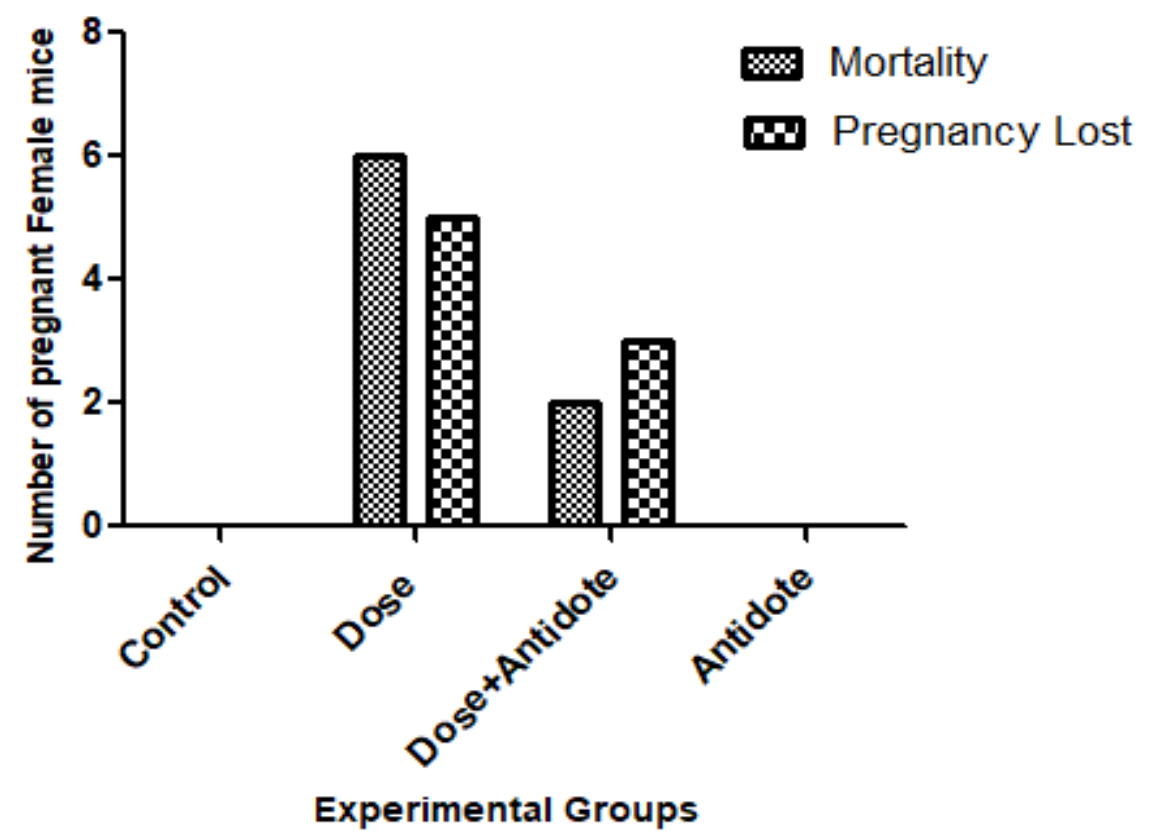

Fig. 4. Mortality rate and pregnancies loss: Histogram showed variation in number of pregnancies lost and mortality rate in all groups. Fifty percent pregnancies were lost in Dose group and forty percent pregnancies lost in (Dose+ Antidote) group. About twenty percent mice died due to arsenic dose in (Dose+ Antidote) group and forty percent in Dose group 
Maternal liver histology

10X

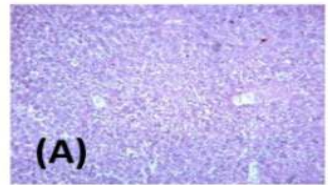

Dose

Dose + Antidote

Antidote
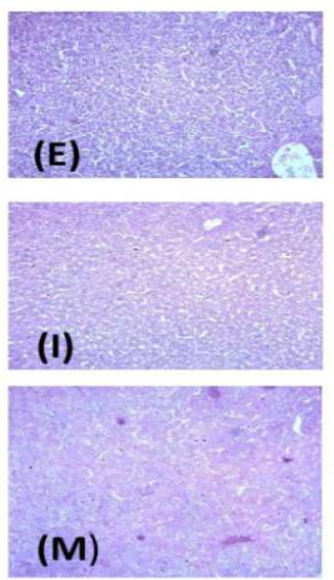

40X
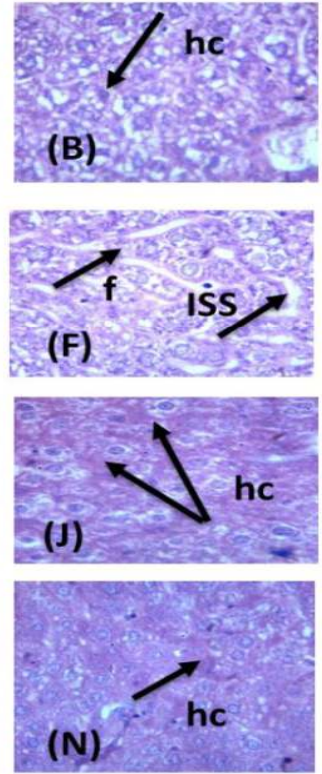

Fetal liver histology

10X

$40 x$
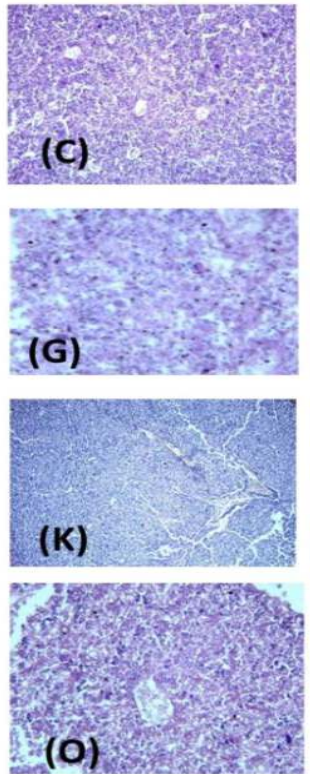
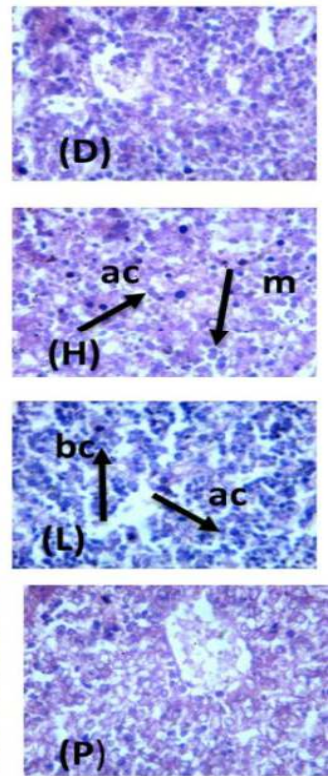

Fig. 5. Morphological changes in maternal and fetal's liver (AandB). Histological cross sections through normal hepatocytes of maternal liver of intact control group $(0.00 \mathrm{mg} / \mathrm{kg} \mathrm{BW})$ at $10 \mathrm{X}$ and $40 \mathrm{X}$. (CandD) Histological cross section through fetal liver in control group $(0.00 \mathrm{mg} / \mathrm{kg} \mathrm{BW})$ showing normal hepatocytes (hc). (EandF) Histological cross sections through maternal liver of Dose group $(50 \mathrm{mg} / \mathrm{kg} \mathrm{BW}$ of arsenic) at 10X and 40X show fibrosis (f) and increased sinusoidal space (ISS). (GandH) Histological cross section through fetal liver of Dose group $(50 \mathrm{mg} / \mathrm{kg} \mathrm{BW})$ showed a nucleated cells (ac), mitosis (m) and pyknosis. (IandJ). Histological cross section of Dose+ Antidote group (50 mg/kg B.W and $30 \mathrm{mg} / \mathrm{kg} \mathrm{BW}$ of garlic maternal liver) at 10X and 40X. (KandL) Histological cross section through fetal liver of Dose+ Antidote group $(50 \mathrm{mg} / \mathrm{kg} \mathrm{BW}$ and 30 $\mathrm{mg} / \mathrm{kg}$ B.W of garlic) showed mitosis (m). (MandN) Histological cross sections through maternal liver of Antidote group (30 mg/kg BW of garlic) at 10X and 40X showed normal hepatocytes. (OandP) Histological cross section of fetal liver in Antidote group (30 mg/kg B.W of garlic) showed normal hepatocytes.

(A)

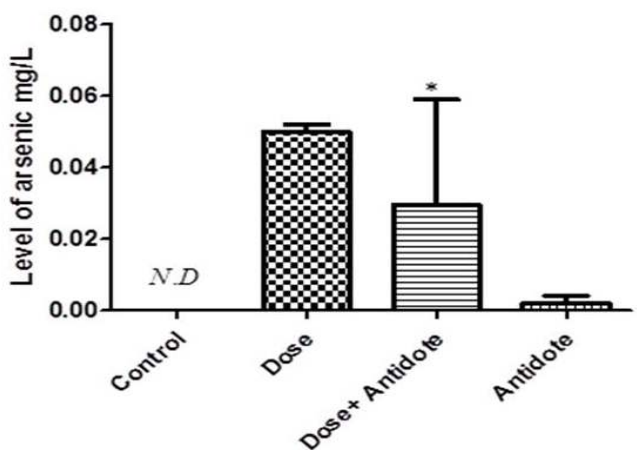

(B)

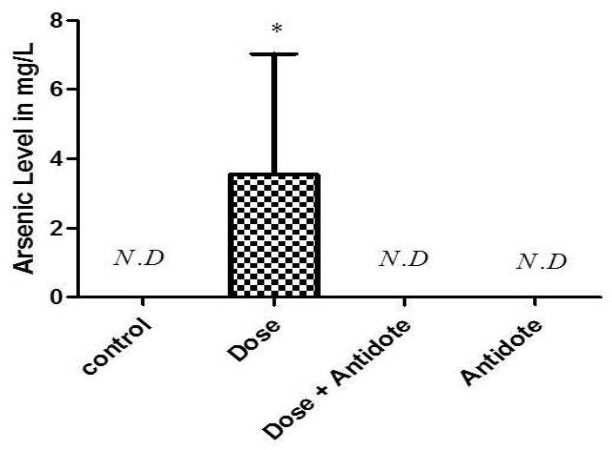

Fig. 6. Accumulation of Arsenic in maternal and fetal liver (A): Graphical representation of metal level estimation in maternal liver of pregnant female mice in Control group $(0.00 \mathrm{mg} / \mathrm{kg} \mathrm{BW})$, Dose group $(50 \mathrm{mg} / \mathrm{kg} \mathrm{BW}$ of arsenic), (Dose + Antidote) group (50 mg/kg BW of arsenic and $30 \mathrm{mg} / \mathrm{kg} \mathrm{BW}$ of garlic) and Antidote group (30 mg/kg BW of garlic). Dose group showed higher level of arsenic in their liver. Arsenic was not detected (N.D) in Control group $\left({ }^{*} \mathrm{p}<0.05\right)$. (B) Histogram showed metal estimation in fetal liver in prenatal exposure to Control group (0.00 mg/kg BW), Dose group (50 mg/kg BW of arsenic), Dose+ Antidote group (50 mg/kg BW of arsenic and $30 \mathrm{mg} / \mathrm{kg} \mathrm{BW}$ of garlic) and Antidote group (30 mg/kg BW of garlic). Arsenic was not detected (N.D) in Control group, Antidote group and Dose+ Antidote group. Dose group showed higher level of arsenic in their liver $\left({ }^{*} \mathrm{p}<0.05\right)$. 


\section{\& Cq Value (Beta actin) \\ Ex Cq Value (NQOH) \\ E Cq Value (HO-1)}

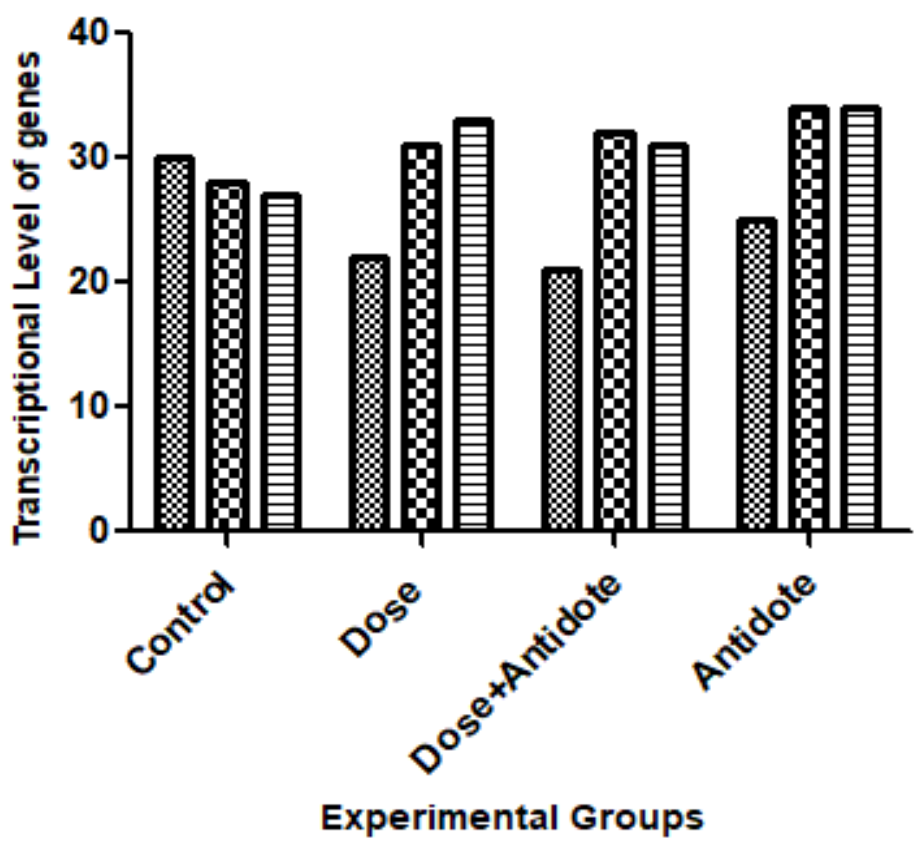

Fig. 7. Up regulation of Nrf2 genes due to garlic treatment: Histogram showed oxidative stress activated the transcriptional level of genes NQO-1 and HO-1. Antioxidant activity of garlic increases the Nrf2/ARE pathway and up regulated the antioxidant enzymes. Garlic has activated the Nrf2 signaling pathway.

Conclusion: Sodium arsenate showed toxicological effects on weight, limbs, size of fetus and liver tissue both in mother mice and fetus during gestation period. It also caused pyknosis, necrosis and increased sinusoidal space, fibrosis and fetal liver in mother. High expression of genes NQO-1 and HO-1 due to oxidative stress was evaluated in pregnant female mice from gestational day $6^{\text {th }}$ to $11^{\text {th. }}$ Up regulation of ARE/Nrf2-Keap 1 pathways represented the primary attempts to neutralize the deteriorative effects produced by arsenic and garlic extract ameliorated the effect in both mother and fetus. Results of morphometric, morphological, histological, molecular and metal estimation indicated that sodium arsenate crossed the placenta and generated teratogen effects in both mother and fetuses. However, potential antioxidant activity of garlic may ameliorate these toxic intensities.

Conflict of interest: The author(s) declare that there is no conflict of interest.

Acknowledgements: University of the Punjab, Lahore, Pakistan is highly acknowledged to support this research.

\section{REFERENCES}

Agarwal, R., A. Chakrabarti, A. Shah, D. Gupta, J. Meis, R. Guleria, R. Moss, D. Denning, and A.C.A.I.W. Group (2013). Allergic bronchopulmonary aspergillosis: review of literature and proposal of new diagnostic and classification criteria. Clin. and Exp. Allergy. 43(8): 850-873.

Amer, S.A., M.S. AL-Harbi, D.Y. Saad, E.A. Mahdi, D.I. Saleh, M.E. Alkafafy, and Y.A. AL-Zahrani (2016). Protective role of some antioxidants on arsenic toxicity in male mice: physiological and histopathological perspectives. Biol. Med. 8:1.

Arshad, Q., S. Siddiqui, S. Ramachandran, U. Goga, A. Bonsu, M. Patel, R. Roberts, Y. Nigmatullina, P. Malhotra, and A. Bronstein (2015). Right hemisphere dominance directly predicts both baseline V1 cortical excitability and the degree of top-down modulation exerted over low-level brain structures. J. Neurosci. 311: 484-489.

Bali, İ., B. Bilir, S. Emir, F. Turan, A. Yılmaz, T. Gökkus, and M. Aydın (2016). The effects of melatonin on liver functions in arsenic-induced liver damage. Turk. J. Surg. 32(4): 233-237. 
Bodaghi-Namileh, V., M.R. Sepand, A. Omidi, M. Aghsami, S.A. Seyednejad, S. Kasirzadeh, and Sabzevari ( 2018). Acetyl-l-carnitine attenuates arsenic-induced liver injury by abrogation of mitochondrial dysfunction, inflammation, and apoptosis in rats. Environ. Toxicol. Pharmacol. 58: 11-20.

Butt, M.S., M.T. Sultan, M.S. Butt, and J. Iqbal (2009). Garlic: nature's protection against physiological threats. Crit. Rev. Food.Sci. Nutr. 49: 538-551.

Castro, C., A.G. Lorenzo, A. González, and M. Cruzado (2010). Garlic components inhibit angiotensin II-induced cell-cycle progression and migration: Involvement of cell-cycle inhibitor p27Kip1 and mitogen-activated protein kinase. Mol. Nutr. Food. Res. 54(6): 781-787.

Choudhury, S., S. Ghosh, S. Mukherjee, P. Gupta, S. Bhattacharya, A. Adhikary, and S. Chattopadhyay (2016). Pomegranate protects against arsenic-induced p53-dependent ROSmediated inflammation and apoptosis in liver cells. J. Nutr. Biochem. 38: 25-40.

Das, B., and K. Chaudhuri (2014). Amelioration of sodium arsenite induced toxicity by diallyl disulfide, a bioactive component of garlic: the involvement of antioxidants and the chelate effect. RSC. Adv. 4: 20964-20973.

Dhawan, V., and S. Jain (2005). Garlic supplementation prevents oxidative DNA damage in essential hypertension. Mol. Cell. Biochem. 275: 85-94.

Fischer, A. H., K.A. Jacobson, J. Rose, and R. Zeller (2008). Paraffin embedding tissue samples for sectioning. CSH protocols. 2008:pdb. prot4989pdb. prot4989.

Flora, S., V. Pachauri, M. Mittal, and D. Kumar (2011). Interactive effect of arsenic and fluoride on cardio-respiratory disorders in male rats: possible role of reactive oxygen species. Biometals. 24(4): 615-628.

Habib, M., S. Bhatti, S. ur Rehman, N. Javed, M.S. Aslam, N. Shahzad, and Z. Abbas (2020). Hepatoprotective role of swimming against arsenic induced oxidative stress in mice. J. King Saud Univ. Sci. 32(1): 822-827.

Han, X.D., Y.Y. Zhang, K.L. Wang, Y.P. Huang, Z.B. Yang, and Z. Liu. (2017). The involvement of $\mathrm{Nrf2}$ in the protective effects of Epigallocatechin-3-gallate (EGCG) on NaAsO2induced hepatotoxicity. Oncotarget. 8(39): 65302-65312.

Hayes, J.D., and M. McMahon (2009). NRF2 and KEAP1 mutations: permanent activation of an adaptive response in cancer. Trends. Biochem. Sci. 34(4): 176-188.

Hill, J., F. Hossain, and B. Sivakumar (2008). Is correlation dimension a reliable proxy for the number of dominant influencing variables for modeling risk of arsenic contamination in groundwater. Stoch. Env. Res. Risk. A. 22: $47-$ 55.

Hsu, L.I., F.I. Hsieh, Y.H. Wang, T.S. Lai, M.M. Wu, C.J. Chen, H.Y. Chiou, and K.H. Hsu (2017). Arsenic exposure from drinking water and the incidence of CKD in low to moderate exposed areas of Taiwan: a 14-Year prospective study. Am. J. Kidney. Dis. 70(6): 787-797.

Jalaludeen, A., W. Ha, R. Lee, J. Kim, J. Do, C. Park, Y. Heo, W. Lee, and H. Song (2016). Biochanin a ameliorates arsenic-induced hepato-and hematotoxicity in rats. Molecules. 21(69): 1-14.

Jiang, T., Z. Huang, J.Y. Chan, and D.D. Zhang (2009). Nrf2 protects against As (III)-induced damage in mouse liver and bladder. Toxicol. Appl. Pharm. 240(1): 8-14.

Khairul, I., Q.Q. Wang, Y.H. Jiang, C. Wang, and H. Naranmandura (2017). Metabolism, toxicity and anticancer activities of arsenic compounds. Oncotarget. 8(14): 23905- 23926.

Kulik-Kupka, K., Koszowska. A, Brończyk-Puzoń. A, Nowak. J, Gwizdek. K, and ZubelewiczSzkodzińska. B (2016). Med Pr. 67:89-96.

Li, L., Q. Liu, L. Fan, W. Xiao, L. Zhao, Y. Wang, W. Ye, F. Lan, B. Jia, and H. Feng. (2017). Protective effects of oxymatrine against arsenic trioxide-induced liver injury. Oncotarget. 8(8): 12792-12799.

Li, Y., Y. Zhang, Y. Gao, W. Zhang, X. Cui, J. Liu, and Y. Wei (2018). Arsenic induces Thioredoxin 1 and apoptosis in human liver HHL-5 cells. Biol. Trace. Elem. Res. 181(2): 234-241.

Lynch, H.N., K. Zu, E.M. Kennedy, T. Lam, X. Liu, D.M. Pizzurro, C.T. Loftus, and L.R. Rhomberg (2017). Quantitative assessment of lung and bladder cancer risk and oral exposure to inorganic arsenic: Meta-regression analyses of epidemiological data. Environ. Int. 106: 178206.

Lu, C., F. Zhao, D. Sun, Y. Zhong, X. Yu, G. Li, X. Lv, G. Sun, and Y. Jin (2014). Comparison of speciated arsenic levels in the liver and brain of mice between arsenate and arsenite exposure at the early life. Environ. Toxicol. 29: 797-803.

Majewski, M. (2014). Allium sativum: facts and myths regarding human health. Rocz. Panstw. Zakl. Hig. 65(1): 1-8

Mandal, P. (2017). Molecular insight of arsenic-induced carcinogenesis and its prevention. Naunyn. Schmiedebergs. Arch. Pharmacol. 390(5): 443455.

Miltonprabu, S., and N. Sumedha (2014). Arsenicinduced hepatic mitochondrial toxicity in rats 
and its amelioration by diallyl trisulfide. Toxicol. Mech. Method. 24(2): 124-135.

Minelli, A., S. Grottelli, A. Mierla, F. Pinnen, I. Cacciatore, and I. Bellezza (2012). Cyclo (HisPro) exerts anti-inflammatory effects by modulating NF- $\mathrm{kB}$ and Nrf2 signalling. J. Biochem. Cell. B. 44(3): 525-535.

Naujokas, M.F., B. Anderson, H. Ahsan, H.V Aposhian, J.H. Graziano, C. Thompson, and W.A. Suk (2013). The broad scope of health effects from chronic arsenic exposure: update on a worldwide public health problem. Environ. Health. Perspect. 121(3): 295-302.

Podder, B., H.Y. Song, and Y.S. Kim (2014). Naringenin exerts cytoprotective effect against paraquatinduced toxicity in human bronchial epithelial BEAS-2B cells through NRF2 activation. J. Mol. Microbiol. Biotechnol. 24(5): 605-613.

Rasheed, H., P. Kay, R. Slack, Y.Y. Gong, and A. Carter (2017). Human exposure assessment of different arsenic species in household water sources in a high risk arsenic area. Sci. Total. Environ. 584: 631-641.

Riaz, N., J.J. Havel, V. Makarov, A. Desrichard, W.J. Urba, J.S. Sims, F.S. Hodi, S. Martín-Algarra, R. Mandal, and W.H. Sharfman. (2017). Tumor and microenvironment evolution during immunotherapy with nivolumab. Cell. 171(4): 934-949. e916.

Roh, T., C.F. Lynch, P. Weyer, K. Wang, K.M. Kelly, and G. Ludewig (2017). Low-level arsenic exposure from drinking water is associated with prostate cancer in Iowa. . Environ. Res. 159: 338-343.

Saint-Jacques, N., L. Parker, P. Brown, and T.J. Dummer (2014). Arsenic in drinking water and urinary tract cancers: a systematic review of 30 years of epidemiological evidence. J. Environ. Health. 13(44): $1-32$

Santhosha, S., P. Jamuna, and S. Prabhavathi (2013). Bioactive components of garlic and their physiological role in health maintenance: A review. Food Biosci. 3: 59-74.
Steinmaus, C., L.E. Moore, M. Shipp., D. Kalman, O.A. Rey, M.L. Biggs, C. Hopenhayn, M.N. Bates, S. Zheng, and J.K. Wiencke (2007). Genetic polymorphisms in MTHFR 677 and 1298, GSTM1 and T1, and metabolism of arsenic. J. Toxicol. Env. Heal. A. 70:159-170.

Tang, W., Y.F. Jiang, M. Ponnusamy, and M. Diallo (2014). Role of Nrf2 in chronic liver disease World. J. Gastroenterol. 20(36): 13079.

Tasnim, S., P.S. Haque, M. Bari, M. Hossain, S.M. Islam, M. Shahriar, M.A. Bhuiyan, B. Sayeed, and M. Shahdaat (2015). Allium sativum L. improves visual memory and attention in healthy human volunteers. Evid. Based. Complementary. Altern. Med. 21:509-528.

Vibol, S., Hashim. J. H, and Sarmani,. S (2015). Neurobehavioral effects of arsenic exposure among secondary school children in the Kandal Province, Cambodia. Environ. Res. 137:329337.

Wang, X., J. Zhang, W. Xu, Q. Huang, L. Liu, M. Tian, Y. Xia, W. Zhang, and H. Shen (2016). Lowlevel environmental arsenic exposure correlates with unexplained male infertility risk. Sci. Total. Environ. 571: 307-313.

Wongsasuluk, P., S. Chotpantarat, W. Siriwong, and M. Robson (2018). Using urine as a biomarker in human exposure risk associated with arsenic and other heavy metals contaminating drinking groundwater in intensively agricultural areas of Thailand. Environ. Geochem. Health. 40(1): 323-348.

Zhang, X., J. Wu, J. Choiniere, Z. Yang, Y. Huang, J. Bennett, and L. Wang (2016). Arsenic silences hepatic PDK4 expression through activation of histone H3K9 methylatransferase G9a. Toxicol. Appl. Pharmacol. 304: 42-47.

Zhao, H., S. Eguchi, A. Alam, and D. Ma (2016). The role of nuclear factor-erythroid 2 related factor 2 (Nrf-2) in the protection against lung injury. Am. J. Physiol. Lung. Cell. Mol. Physiol. 312(2): 155-162. 